\title{
Assessment of Obesity and Circadian Rhythm Irregularities of Disabled People
}

\author{
Müge Arslan ${ }^{1}$, Müveddet Emel Alphan² \\ ${ }^{1}$ Department of Nutrition and Dietetics, İstanbul Arel University, İstanbul, Turkey \\ ${ }^{2}$ Departmant of Nutrition and Dietetics, Okan University, Istanbul, Turkey
}

Email address:

dyt_muge@hotmail.com (M. Arslan)

\section{To cite this article:}

Müge Arslan, Müveddet Emel Alphan. Assessment of Obesity and Circadian Rhythm Irregularities of Disabled People. Journal of Food and Nutrition Sciences. Vol. 6, No. 1, 2018, pp. 18-23. doi: 10.11648/j.jfns.20180601.13

Received: November 8, 2017; Accepted: November 16, 2017; Published: December 20, 2017

\begin{abstract}
Circadian rhythm is responsible for regulation of metabolic systems. Irregularities of circadian rhythm is thought to be increasing risk factor for metabolic disorders like obesity. The aim of the current study is to examine this relationship and understand mediatory effects of daily dietary habits in this relationship for disabled people. 103 subjects (56 male, 47 female) from an Education and Rehabilitation Centre of Disabled People in Çorum in Turkey participated to the study. The subjects' sleep quality was assessed with Pittsburg Sleep Quality Inventory (PSQI). BMI levels was used for obesity diagnosis. Daily dietary habits and calorie intake of subjects were also measured by survey and daily food consumption recordings for 7 days. $28,2 \%$ of the subjects diagnosed with obesity according to BMI levels. $38,8 \%$ of the subjects are found to be having bad sleep quality. There is a positive significant relationship between obesity and bad sleep quality. Daily carbohydrate, protein and fat intake is also found to be positively related with bad sleep quality. As a result, findings of the current study indicates the effect of circadian rhythm on daily dietary habits which further leading to increased obesity risk for disabled people.
\end{abstract}

Keywords: Obesity, Circadian Rhythm, Dietary Habits, Disability

\section{Introduction}

In the last few decade, obesity has gained much attention as a public health hazard in most countries due to its extensive harm on human body. It is a disease associated with excessive fat accumulation in body $[1,2]$. Diagnosis of obesity bases on body measurement. This measurement method called as body mass index (BMI) and is obtained by dividing the weight by the square of the height [3]. The criteria for obesity has changed in years due to definition of it and the population that is considered [4]. However, World
Health Organization (WHO) standardized the criteria as it shown in the Table 1. According to these criteria $<16 \mathrm{BMI}$ is defined as extremely thin, $<18$ as thin and $\geq 25$ as obese $[5,6$, $7,8]$. However, these cut-offs may show slight changes according to age, sex and the country [9, 10]. For example, WHO identified 20-30BMI as normal and $>33$ obesity for women while the normal limit is $12-20 \mathrm{BMI}$ and the obesity limit is $>25$ for men in later studies.

Table 1. International classification for BMI.

\begin{tabular}{lll}
\hline Classification & Cut-off $\left(\mathbf{k g} / \mathbf{m}^{2}\right)$ & BMI $\left(\mathbf{k g} / \mathbf{m}^{2}\right)$ (Additional cut-off) \\
\hline Thin & $<18,00$ & $<18,5$ \\
Average weight & $18,50-24,99$ & $18,50-22,99$ \\
& & $23,00-24,99$ \\
Over weight & $25,00-29,99$ & $25,00-27,49$ \\
& & $27,50-29,99$ \\
\hline
\end{tabular}




\begin{tabular}{lll}
\hline Classification & Cut-off $\left.\mathbf{( k g} / \mathbf{m}^{2}\right)$ & BMI $\left(\mathbf{k g} / \mathbf{m}^{2}\right)$ (Additional cut-off) \\
\hline Obese & $\geq 30,00$ & $\geq 30,00$ \\
1. class & $30,00-34,99$ & $30,00-32,49$ \\
& & $32 ., 0-34,99$ \\
2. class & $35,00-39,99$ & $35,00-37,49$ \\
& & $37,50-39,99$ \\
3. class & $\geq 40,00$ & $\geq 40,00$ \\
\hline
\end{tabular}

Obesity is seen as a trigger of many chronic and fatal diseases such as diabetes and hypertension [11], and its prevalence increases every year. According to MONICA study of WHO which has lasted for 12 years, the prevalence of obesity increase $10-30 \%$ in only ten years. CDC (Center for Disease Control), on the other hand, present this increase rate as approximately $35 \%$ between 2003-2010 [12]. This increase bases on many factors, but the most important one may be the dietary habit of people. People consume more than 50 different nutrients according to their dietary habits. These nutrients can be grouped in 6 categories. These are carbohydrates, proteins, fat, vitamins, minerals and water [13]. Daily calorie need is met with carbohydrates in 45$65 \%$, with proteins in $10-12 \%[14,15]$ and with fat in 20 $35 \%$ [15] in a normal dietary. Vitamins and minerals, on the other hand, contribute to the sustainability of human health and various diseases and developmental disorders emerge in the case of deficiency of them $[14,16,17]$.

Studies show that circadian rhythm is one of the factors that pose high risk for obesity in daily routine $[18,19]$. Circadian rhythm is a 24-hour endogenous biological rhythm. All biological oscillation of the body like hormone releases are set to it $[7,8,20]$. Therefore, changes in circadian rhythm cause irregularities in hormone releases and associative diseases [21-23]. One of them is leptin hormone that regulates appetite. Studies indicate that leptin hormone level decreases due to circadian rhythm irregularities and led to increased appetite and weight gain $[18,19]$. Also, increase in ghrelin hormone is found to be related with decrease in leptin hormone in further studies. Ghrelin hormone also causes increase in appetite and hunger which further increase the weight gain [24, 25].

Many of these studies based on examining the circadian rhythm and obesity relationship through sleep irregularities. It is because one of the significant indicator of the circadian rhythm irregularities is sleep irregularities and disorders. According to findings, short sleep is associated with high BMI and type-2 diabetes [26, 27]. Especially, BMI is find to have negative relationship with sleep duration [28]. Therefore, people with sleep disorder are defined as under high risk of developing obesity [29, 30].

Circadian rhythm irregularities also effect dietary habits. Findings show that effect of energy expenditure on metabolism changes according to biological time of the body. People who work at night or with disorders like night eating syndrome are found to have tendency to increased BMI and to develop obesity due to continuing calorie intake during a time they should be sleeping $[28,31,32,33]$. On the other hand, type of nutrients in daily dietary is found to be related with gene expressions that join into metabolism and regulation of circadian rhythm [34, 35]. In Kohsaka and his colleagues study, high-fat diet is found to changing locomotor activities of rodents and increasing their calorie intake during both day and night times [36]. Thus, the relationship between dietary habit and circadian rhythm may be interpreted as bi-directional. In terms of studies on this relationship, there is lack of research on people with disabilities. The current study focus on disabled people to understand this relationship. During the study, daily dietary habits and calorie intake of subjects are also assessed to understand possible effect of them on this relationship.

\section{Subjects and Method}

\subsection{Subjects}

This study is conducted with disabled people from an Education and Rehabilitation Centre of Disabled People in Çorum in Turkey. Ethical approval of the current study was given by the ethical committee of Okan University Institute of Health Sciences according to research protocol number 75 in 30.03.2016. Data was collected between April and June in 2016. Only people who does not have any mental or psychological disorder and whose families consent for participation to study are recruited. The total number of subjects is 103 (Male $=56$, Female $=47)$. Their age is ranged between 18 to $74(M=32,17, S t d=10,43)$.

\subsection{Measurement}

Circadian rhythm of the subjects was measured through their sleeping cycle in this study. Evaluation of the subjects' sleep cycle was done by using Turkish version of Pittsburgh Sleep Quality Index (PSQI) [37]. Usage of this index requires both the subjects and one of their first degree relatives' answers. The index consists of sub-factors as sleep quality, sleep latency, sleep duration, habitual sleep efficiency, sleep disturbances, use of sleeping medications and daytime dysfunction factors. Total score of 5 or below considered as having "good" sleep, while total score of higher than 5 considered as having "bad" sleep for this index. "Bad" sleep quality refers to high sleep disturbance in at least two subfactors, or it may refer to mild sleep disturbance in more than three sub-factors in the index according to answers of subject.

In this study, obesity was measured through BMI. For this purpose, anthropometric measurements were used. Weight of 
the subjects was measured by Fakir Herculus Body Analyzing Bascule (sensitive to $100 \mathrm{~g}$ ) for who can stand themselves. Those subjects' height was measured with tape measure in standing position. On the other hand, weight of subjects who cannot stand themselves was measured using a chair. Ekoter B5 Electronic Weight Scale (with $150 \mathrm{~kg}$ weighing capacity) was used for weight measurement and tare of the chair was excluded from the total weight. Their height was measured while they were lying on their backs. Daily dietary habits and calorie intake was assessed with a survey consisting of 36 questions and daily food consumption recordings of each subject for 7 days.

\section{Results}

The data of the study was analyzed with SPSS v.22 program. Normal distribution of the data was controlled with Kolmogorov-Smirnov $\mathrm{Z}$ test. In all analyses 5\% significance value was used to evaluate results.

According to BMI measurements, $28,2 \%$ of the subjects are diagnosed with obesity in Table 2 Distribution of anthropometric measurements and BMI according to age and sex are presented in Table 3. No significant difference between male and female subjects was found for BMI levels, $P>0,05$.

Table 2. BMI of the subjects.

\begin{tabular}{llll}
\hline & Thin $(\leq 18,5)$ & 12 & 11,7 \\
BMI $\left(\mathrm{kg} / \mathrm{m}^{2}\right)$ & Average weight $(18,5-24,99)$ & 42 & 40,8 \\
& Over weight $(25-29,99)$ & 20 & 19,4 \\
& Obese $(30-39,99)$ & 29 & 28,2 \\
\hline
\end{tabular}

Table 3. Distribution of anthropometric measurements.

\begin{tabular}{lllllll}
\hline & \multicolumn{1}{l}{ SEX } & & & \\
\cline { 2 - 7 } & MALE & & \multicolumn{3}{c}{ FEMALE } & \\
\hline Features & Min-Max & Median & M \pm Std & Min-Max & Median & M \pm Std \\
\hline Age (year) & $19-74$ & 29,5 & $31,46 \pm 10,63$ & $18-59$ & 31 & $33,02 \pm 10,24$ \\
Weight (kg) & $42-120$ & 68 & $71,43 \pm 18,2$ & $30-113$ & 60 & $63,6 \pm 16,86$ \\
Height (cm) & $147-188$ & 168,5 & $167,84 \pm 9,33$ & $120-177$ & 160 & $158,04 \pm 14,02$ \\
Waist Circumference (cm) & $62-120$ & 92,5 & $92,25 \pm 16,63$ & $60-129$ & 86 & $87,02 \pm 16,4$ \\
BMI $\left(\mathrm{kg} / \mathrm{m}^{2}\right)$ & $20,9-45,7$ & 24,9 & $25,55 \pm 6,71$ & $21,2-46,8$ & 24,6 & $25,78 \pm 6,91$ \\
\hline
\end{tabular}

PSQI scores of the participants are found to be ranging between 0 to $13(\mathrm{M}=5,15 ; \mathrm{SD}=03)$. According to these scores, $38,8 \%(N=40)$ of the subjects have bad sleep quality in Table 4. When the scores are evaluated according to sex, it is found that $32,1 \%$ of male subjects and $46,8 \%$ of female subjects have bad sleep quality in Table 4 . However, there is no significant difference between two groups, $P>0,05$.

Table 4. Distribution of sleep quality criteria $(N=103)$.

\begin{tabular}{|c|c|c|c|c|c|c|c|c|}
\hline \multirow{3}{*}{ Sleep Quality Criteria } & \multicolumn{8}{|c|}{ PSQI score } \\
\hline & \multicolumn{2}{|l|}{$\mathbf{0}$} & \multicolumn{2}{|l|}{1} & \multicolumn{2}{|l|}{2} & \multicolumn{2}{|l|}{3} \\
\hline & $\mathbf{n}$ & $\%$ & $\mathbf{n}$ & $\%$ & $\mathbf{n}$ & $\%$ & $\mathbf{n}$ & $\%$ \\
\hline PSQI- Sleep Quality & 26 & 25,2 & 66 & 64,1 & 6 & 5,8 & 5 & 4,9 \\
\hline PSQI- Sleep Latency & 43 & 41,7 & 21 & 20,4 & 33 & 32,0 & 6 & 5,8 \\
\hline PSQI- Sleep Duration & 71 & 68,9 & 13 & 12,6 & 17 & 16,5 & 2 & 1,9 \\
\hline PSQI- Habitual Sleep Efficiency & 70 & 68,0 & 18 & 17,5 & 7 & 6,8 & 8 & 7,8 \\
\hline PSQI- Sleep Disturbances & 14 & 13,6 & 83 & 80,6 & 6 & 5,8 & 0 & 0 \\
\hline PSQI- Use of Sleeping Medications & 49 & 47,6 & 48 & 46,6 & 1 & 1,0 & 5 & 4,9 \\
\hline PSQI- Daytime Dysfunction & 44 & 42,7 & 55 & $\begin{array}{l}53,4 \\
\mathrm{n}\end{array}$ & 3 & 2,9 & $\begin{array}{l}1 \\
\%\end{array}$ & 1,0 \\
\hline PSQI total score & \multicolumn{3}{|c|}{$\begin{array}{l}\text { Min-Max. } \\
M \pm \text { Std }\end{array}$} & \multicolumn{3}{|c|}{$0-13$} & & \\
\hline \multirow{2}{*}{ Sleep Quality } & \multicolumn{3}{|c|}{ Good } & \multirow{2}{*}{\multicolumn{3}{|c|}{$\begin{array}{l}63 \\
40\end{array}$}} & \multicolumn{2}{|l|}{61,2} \\
\hline & \multicolumn{3}{|c|}{$\mathrm{Bad}$} & & & & 38,8 & \\
\hline
\end{tabular}

The relationship between BMI measurements and sleep quality scores is analyzed based on the one of the aims of this study. Pearson Chi-Square (Fisher's Exact) Test was used considering both male and female subjects. A significant relationship between BMI and sleep quality is found in total,
$P<0,01$. This significant relationship is also significant for both male $(P<0,01)$ and female $(P<0,05)$ subjects. Results showed that subjects with obesity diagnosis have bad sleep quality in Table 5. 
Table 5. Correlation between sleep quality and BMI levels $(N=103)$.

\begin{tabular}{|c|c|c|c|c|c|c|c|c|c|c|c|}
\hline \multirow[b]{3}{*}{ Sex } & \multirow[b]{3}{*}{ Sleep Quality } & \multicolumn{10}{|c|}{ Body Mass Index (BMI) levels } \\
\hline & & \multicolumn{2}{|c|}{ Thin } & \multicolumn{2}{|c|}{ Average Weight } & \multicolumn{2}{|c|}{ Over Weight } & \multicolumn{2}{|c|}{ Obese } & \multirow[b]{2}{*}{$X^{2}$} & \multirow[b]{2}{*}{$\mathbf{P}$} \\
\hline & & $\mathbf{n}$ & $\%$ & $n$ & $\%$ & $\mathrm{n}$ & $\%$ & $\mathbf{n}$ & $\%$ & & \\
\hline \multirow{2}{*}{ Male } & Good & 7 & 18,4 & 12 & 31,6 & 12 & 31,6 & 7 & 18,4 & \multirow{2}{*}{ - } & \multirow{2}{*}{$0,008 * *$} \\
\hline & $\mathrm{Bad}$ & 2 & 11,1 & 7 & 38,9 & 0 & 0 & 9 & 50,0 & & \\
\hline \multirow{2}{*}{ Female } & Good & 2 & 8,0 & 13 & 52 & 7 & 28,0 & 3 & 12,0 & \multirow{2}{*}{-} & \multirow{2}{*}{$0,022 *$} \\
\hline & $\mathrm{Bad}$ & 1 & 4,5 & 10 & 45,5 & 1 & 4,5 & 10 & 45,5 & & \\
\hline \multirow{2}{*}{ Total } & Good & 9 & 14,3 & 25 & 39,7 & 19 & 30,2 & 10 & 15,9 & \multirow{2}{*}{9,003} & \multirow{2}{*}{$0,029 *$} \\
\hline & $\mathrm{Bad}$ & 3 & 7,5 & 17 & 42,5 & 1 & 2,5 & 19 & 47,5 & & \\
\hline
\end{tabular}

$\mathrm{X}^{2}=$ Pearson Chi-Square (Fisher's Exact )Test; ${ }^{*} \mathrm{p}<0,05 * * \mathrm{p}<0,01$

Daily carbohydrate, protein and fat intake of the subjects and their distribution according to sleep quality are presented in Table 6. When PSQI scores considered, a significant relationship is found between PSQI scores and carbohydrate,
( $\mathrm{r}=0,490 ; P=0,000)$, PSQI scores and protein intake $(\mathrm{r}=$ $0,319 ; P<0,01)$, and PSQI scores and fat intake $(\mathrm{r}=0,198 ; P$ $<0,05)$. These results indicate that daily carbohydrate, protein and fat intake increases as PSQI scores increases.

Table 6. Sleep quality mean scores and carbohydrate, protein and fat levels $(N=103)$.

\begin{tabular}{|c|c|c|c|c|c|c|c|}
\hline & & \multicolumn{6}{|c|}{ Sleep Quality } \\
\hline & & \multicolumn{3}{|l|}{ Good } & \multicolumn{3}{|l|}{ Bad } \\
\hline & & Min-Max & Median & $\mathbf{M} \pm$ Std & Min-Max & Median & $\mathbf{M} \pm$ Std \\
\hline \multirow{3}{*}{ Male $(n=56)$} & Carbohydrate\% & $26-58$ & 43,5 & $44,13 \pm 6,39$ & $37-59$ & 50,5 & $48,94 \pm 5,02$ \\
\hline & Protein $\%$ & $10-25$ & 19 & $18,84 \pm 3,13$ & $15-21$ & 18 & $17,56 \pm 1,65$ \\
\hline & Fat $\%$ & $27-49$ & 36,5 & $36,95 \pm 5,10$ & $25-43$ & 34 & $33,72 \pm 4,56$ \\
\hline \multirow{3}{*}{ Female $(n=47)$} & Carbohydrate\% & $31-53$ & 43 & $42,72 \pm 6,85$ & $32-55$ & 49 & $46,64 \pm 6,87$ \\
\hline & Protein $\%$ & $15-27$ & 17 & $18,32 \pm 3,34$ & $14-23$ & 18,5 & $18,18 \pm 2,28$ \\
\hline & Fat $\%$ & $32-49$ & 39 & $39,24 \pm 4,98$ & $28-47$ & 34 & $35,59 \pm 6,07$ \\
\hline \multirow{3}{*}{ Total } & Carbohydrate\% & $26-58$ & 43 & $43,57 \pm 6,56$ & $32-59$ & 50 & $47,68 \pm 6,15$ \\
\hline & Protein $\%$ & $10-27$ & 18 & $18,63 \pm 3,20$ & $14-23$ & 18 & $17,90 \pm 2,02$ \\
\hline & $\mathrm{Fat} \%$ & $27-49$ & 38 & $37,86 \pm 5,14$ & $25-47$ & 34 & $34,75 \pm 5,46$ \\
\hline
\end{tabular}

Daily energy intake of the subjects is also analyzed according to sleep quality. Independent sample t-test was used to compare energy intake of the subjects who have bad sleep quality and who have good sleep quality. Results showed that the subjects with bad sleep quality $(M=2210$; $S t d=569)$ have higher energy intake than the subjects with good sleep quality $(M=1370 ; S t d=500),(P=0,000)$.

\section{Discussion}

The findings of the study revealed a relationship between sleep irregularity and obesity. Due to its importance as an indicator for circadian rhythm, irregularity in sleep cycle is interpreted as an irregularity in circadian rhythm in this study. Thus, the findings of the study present a relationship between circadian rhythm disturbance and obesity. This finding is also supported by previous studies of Bidulescu and his collegues of Hung and his colleagues and of Tamakoshi and his collegues and of Varana and his colleagues. In their study, Bidulescu, Hung, Tamakoshi, Varana and their colleagues reported a higher obesity risk for people who have bad sleep quality $[21,38,39,40]$ On the other hands, the findings of Yan's study revealed any relationship between sleep irregularity and obesity. [41]

The findings of the study revealed a relationship between sleep irregularity and consumption of carbohydrate and fat. As the consumption of carbohydrates and fats increases, sleep quality decreases. This finding is also supported by previous studies of
Chaput, Katagiri, Yoneyama and of Öçal and his collegues. In their study, Chaput, Katagiri and Yonema reported as consumption of carbonhydrates increases, sleep quality decreases. [42, 43, 44] Öçal reported as consumption of fat increases sleep quality decreases. [37]

\section{Conclusion}

Disabled people have limited mobility according to type and degree of their disability. This situation effects their life quality and body health diversely. However, there are lack of researches on disabled people in literature. Thus, the current study focuses on BMI levels and sleep quality of disabled people. Half of the subjects found to be having high BMI level, in our study while almost $30 \%$ of the subjects are in level of obesity. Although, this results may be resulted from restricted movements of body, bad sleep quality is also found to be related with obesity in the current study. Sleep quality is considered as an indicator of circadian rhythm [18, 28]. Previous studies show that circadian rhythm has many effects on metabolic system of body [7,8]. Therefore, obesity rate in the subjects can be interpreted as not a result of limited body movement, but as a result of circadian rhythm irregularities.

Due to its effects on metabolism, circadian rhythm is associated with irregular dietary and increased energy intake [34-36]. To assess the effect of circadian rhythm on obesity, daily dietary habits and energy intake is also evaluated. The results showed that daily carbohydrate, fat and protein intake is positively increases as PSQI scores increases which is 
associated with bad sleep quality. Daily calorie intake is also found to be positively correlated with bad sleep quality. These finding are in parallel with several studies that present comorbidity of sleep disorders with other disorders such as night eating syndrome which finally leads to increased risk of obesity and diabetes [28, 45, 46, 47]. When all of these results considered, increased risk of obesity of disabled people can be interpreted as a result of circadian rhythm irregularities rather than limited body movements due to its increasing effect on daily energy intake.

\section{Funding Source}

There was no funding or financial grants received for this study.

\section{Conflict of Interest}

There are no conflicts of interest in the publication of this study.

\section{References}

[1] WHO. Physical status: the use and interpretation of anthropometry, Report of a WHO Expert Committee [Internet]. WHO Technical Report Series 854, Geneva, Switzerland: World Health Organization; 1995 [cited 15 May 2016]. Available from: http://www.who.int/childgrowth/publications/physical_status/ en/

[2] WHO. Obesity: preventing and managing the global epidemic. WHO Technical Report Series 894, Geneva, Switzerland: World Health Organization; 2000.

[3] Health implications of obesity: National Institutes of Health consensus development conference statement. Annals of Internal Medicine 1985;103(1):147-151.

[4] Jarrett RJ. Is there an ideal body weight?. British Medical Journal 1986;293(6545):493-495.

[5] Cappuccio FP, Cooper D, D'Elia L, Strazzullo P, Miller MA. Sleep duration predicts cardiovascular outcomes: a systematic review and meta-analysis of prospective studies. European Heart Journal 2011;32(12):1484-92.

[6] Moore RY. Circadian rhythms: Basic neurobiology and clinical applications. Annual Review of Medicine 1997;48(1):253-266.

[7] Mohawk JA, Green CB, Takahashi JS. Central and peripheral circadian clocks in mammals. Annual Review of Neuroscience 2012;35:445-462.

[8] Maury E, Ramsey KM, Bass J. Circadian rhythms and metabolic syndrome: from experimental genetics to human disease. Circulation Research 2010;106(3):447-462.

[9] Cole TJ, Bellizzi MC, Flegal KM, Dietz WH. Establishing a standard definition for child overweight and obesity worldwide: international survey. The British Medical Journal 2000;320(7244):1240-1243.

[10] Türkiye Halk Sağlığı Kurumu, Obezite Nedir? [Internet]. [cited 12 December 2015]. Available from: http://beslenme.gov.tr/index.php?lang=tr\&page=38.

[11] Sağlık Bakanlığı. Sağlık 21 Herkese Sağlık, Türkiye'nin Hedef ve Stratejileri. Ankara: Sağlık Bakanlığı Yayını; 2001. p.27-28.

[12] Türkiye Halk Sağlı̆ğ Kurumu. Dünyada Obezitenin Görülme Sıklığı [Internet]. Ankara: T. C Sağlık Bakanlığı Türkiye Halk Sağlığı Kurumu; 2013 [cited 17 April 2014]. Available from: $\mathrm{http}$ ://beslenme.gov.tr/index.php?lang $=$ tr\&page $=39$

[13] Koktay O. Afyonkarahisar Devlet Hastanesi'nde Ayakta Tedavi Gören Obez Yetişkin (20-65 Yaş) Hastaların Beslenme Bilgi Düzeylerinin ve Beslenme Alışkanlıklarının Saptanması (Master's Thesis). Afyon: Afyon Kocatepe University; 2011.

[14] Baysal, A. Beslenme. Ankara: Hatiboğlu Yayınları; 2008.

[15] T. C Sağlık Bakanlığı Türkiye Halk Sağlığı Kurumu. Türkiye Beslenme Rehberi 2015 (TÜBER) [Internet]. Ankara; 2016 [cited 18 March 2016]. Available from: https://okulsagligi.meb.gov.tr/meb_iys_dosyalar/2017_01/271 02535 TYrkiye_Beslenme_Rehberi.pdf.

[16] Center for Magnesium Education \& Research, LLC. The Essential Nutrients. [cited 12 April 2016]. Available from: $\mathrm{http}: / / w w w . m a g n e s i u m e d u c a t i o n . c o m / e s s e n t i a l-n u t r i e n t s-f o r-$ humans.

[17] NHS Choices. Vitamins and minerals. [cited 15 April 2016]. Available from: http://www.nhs.uk/Conditions/vitaminsminerals/Pages/vitamins-minerals.aspx.

[18] Scheer FA, Hilton MF, Mantzoros CS, Shea SA. Adverse metabolic and cardiovascular consequences of circadian misalignment. Proceedings of the National Academy of Sciences 2009;106(11):4453-4458.

[19] Buxton OM, Cain SW, O'Connor SP, Porter JH, Duffy JF, Wang W, et al. Adverse metabolic consequences in humans of prolonged sleep restriction combined with circadian disruption. Science Translational Medicine 2012; 4(129):129ra43.

[20] Yoshino J, Klein S. A novel link between circadian clocks and adipose tissue energy metabolism. Diabetes 2013;62(7):21752177.

[21] Vorona RD, Winn MP, Babineau TW, Eng BP, Feldman HR, Ware JC. Overweight and obese patients in a primary care population report less sleep than patients with a normal body mass index. Archives of Internal Medicine 2005;165(1):25-30.

[22] Vgontzas AN, Mastorakos G, Bixler EO, Kales A, Gold PW, Chrousos GP. Sleep deprivation effects on the activity of the hypothalamic-pituitary-adrenal and growth axes: potential clinical implications. Clinic Endocrinology 1999;51(2):205-15.

[23] Leger D. The cost of sleep-related accidents: a report for the National Commission on Sleep Disorders Research. Sleep 1994;17(1):84-93.

[24] Taheri S, Lin L, Austin D, Young T, Mignot E. Short sleep duration is associated with reduced leptin, elevated ghrelin, and increased body mass index. PLoS Med 2004;1(3):e62.

[25] Spiegel K, Tasali E, Penev P, Van Cauter E. Brief communication: Sleep curtailment in healthy young men is associated with decreased leptin levels, elevated ghrelin levels, and increased hunger and appetite. Annals of Internal Medicine 2004;141(11):846-850. 
[26] Spiegel K, Tasali E, Leproult R, Van Cauter E. Effects of poor and short sleep on glücose metabolism and obesity risk. Nature Reviews Endocrinology 2009;5(5):253-261.

[27] Itani O, Kaneita Y, Murata A, Yokoyama E, Ohida T. Association of onset of obesity with sleep duration and shift work among Japanese adults. Sleep Medicine 2011;12(4):341345 .

[28] Markwald RR, Melanson EL, Smith MR, Higgins J, Perreault L, Eckel RH, Wright KP. Impact of insufficient sleep on total daily energy expenditure, food intake, and weight gain. Proceedings of the National Academy of Sciences 2013;110(14):5695-700.

[29] Liu J, Hay J, Faught BE. The association of sleep disorder, obesity status, and diabetes mellitus among US adults-the NHANES 2009-2010 survey results. International Journal of Endocrinology 2013:1-6.

[30] Phillips BG, Kato M, Narkiewicz K, Choe I, Somers VK. Increases in leptin levels, sympathetic drive, and weight gain in obstructive sleep apnea. American Journal of PhysiologyHeart and Circulatory Physiology 2000;279(1):234-237.

[31] Goel N, Stunkard AJ, Rogers NL, Van Dongen HP, Allison $\mathrm{KC}$, O'Reardon JP, et al. Circadian rhythm profiles in women with night eating syndrome. Journal of Biological Rhythms 2009;24(1):85-94.

[32] Lowden A, Moreno C, Holmback U, Lennernas M, Tucker P. Eating and shift work - effects on habits, metabolism and performance. Scandinavian Journal of Work, Environment \& Health 2010;36(2):150-62.

[33] Debry G, Girault P, Lefort J, Thiebault J. Survey of the food habits of workers on shift work. Bulletin de l'Institut National de la Santé et de la Recherche Médicale 1967;22(6):1169-202.

[34] Havel PJ, Townsend R, Chaump L, Teff K. High-fat meals redüce 24-h circulating leptin concentrations in women. Diabetes 1999;48(2):334-341.

[35] Cano P, Jiménez-Ortega V, Larrad A, Toso CFR, Cardinali DP, Esquifino AI. Effect of a high-fat diet on 24-h pattern of circulating levels of prolactin, luteinizing hormone, testosterone, corticosterone, thyroid-stimulating hormone and glucose, and pineal melatonin content, in rats. Endocrine 2008;33(2):118-125.

[36] Kohsaka A, Laposky AD, Ramsey KM, Estrada C, Joshu C, Kobayashi Y, et al. High-fat diet disrüpts behavioral and molecülar circa-dian rhythms in mice. Cell Metabolism 2007;6(5):414-421.
[37] Öçal Ö. Acıbadem maslak hastanesi beslenme ve Diyet polikliniğine başvuran yetişkin Bireylerde besin tüketiminin Pittsburgh Uyku kalitesi ölçeği ile ilişkisi [Master's Thesis]. Ankara: Başkent University; 2015.

[38] Bidulescu A, Din-Dzietham R, Coverson DL et al. "Interaction of sleep quality and psychosocial stress on obesity in African Americans: the Cardiovascular Health Epidemiology Study (CHES)", BMC Public Health, 2010;10:581.

[39] Tamakoshi A, Ohno Y. "Self reported sleep duration as a predictor of all-cause mortality: results from the JACC study, Japan", Sleep, 2004; 27:51-54.

[40] Hung H, Yang Y, Wu J, Lu F. "Sleep quality and overweight in a Chinese population", Obesity, 2013, 21, 486-492.

[41] Yan Z, Chang-Quan H, Zhen-Chan L, Bi-Rong D. "Association between sleep quality and body mass index among Chinese nonagenarians/centenarians", Age (Dordr), 2012, Jun;34(3): 527-537.

[42] Chaput JP, Tremblay A. "Does short sleep duration favor abdominal adiposity in children", Int $J$ Pediatr Obes, 2007;2:188-191.

[43] Katagiri R, Asakura K, Kobayashi S, Suga H, Sasaki S. "low intake of vegetables, high intake of confectionary, and unhealthy eating habits are associated with poorsleep quality among middle-aged female Japanese workers", J Occup Health, 2014; 56(5):359-368.

[44] Yoneyama S, Sakurai M, Nakamura K, Morikawa Y, Miura K, et al. "Associations between Rice, Noodle, and Bread Intake and Sleep Quality in Japanese Men and Women", PLoS One, 2014; 9(8): e105198.

[45] Wolk R, Shamsuzzaman AS, Somers VK. Obesity, sleep apnea, and hypertension. Hypertension 2003;42(6):1067-1074.

[46] Birketvedt GS, Florholmen J, Sundsfjord J, Østerud B, Dinges D, Bilker W, Stunkard A. Behavioral and neuroendocrine characteristics of the night-eating syndrome. Jama 1999;282(7):657-63.

[47] Allison KC, Lundgren JD, O'Reardon JP, Geliebter A, Gluck $\mathrm{ME}$, Vinai $\mathrm{P}$, et al. Proposed diagnostic criteria for night eating syndrome. International Journal of Eating Disorders 2010;43(3):241-7. 